\title{
Electrocardiographic markers of myocardial conduction and repolarization in Boxer $\operatorname{dogs}{ }^{1}$
}

\author{
Elizabeth Regina Carvalho ${ }^{2 *}$ (D), Evandro Zacché2, Michelli Fenerich ${ }^{2}$, \\ Aparecido Antônio Camacho ${ }^{2}$, Julio P. Santos ${ }^{3}$ and Marlos G. Sousa ${ }^{3}$
}

\begin{abstract}
Carvalho E.R, Zacché E., Fenerich M., Camacho A.A., Santos J.P. \& Sousa M.G. 2020. Electrocardiographic markers of myocardial conduction and repolarization in Boxer dogs. Pesquisa Veterinária Brasileira 40(8):630-636. Faculdade de Ciências Agrárias e Veterinárias, Universidade Estadual Paulista “Júlio do Mesquita Filho", Via de Acesso Prof. Paulo Donato Castellane s/n, Jaboticabal, SP 14884-900, Brazil. E-mail: beth_rcarvalho@hotmail.com

Electrocardiographic markers have been used in people to classify arrhythmogenic risk. The aims of this study were to investigate electrocardiographic markers of conduction and repolarization in Boxers and non-Boxer dogs, and compare such findings between groups. Ten-lead standard electrocardiograms of Boxer dogs and non-Boxers recorded from 2015 to 2018 were retrospectively reviewed. Dogs $\geq 4$ years of age and weighing $>20 \mathrm{~kg}$ were included. Animals with valvular insufficiencies, congenital cardiopathies, cardiac dilation, suspected systolic dysfunction, biphasic T-wave, bundle branch blocks, and those receiving antiarrhythmics were excluded. Electrocardiographic markers of conduction, QRS duration $\left(\mathrm{QRS}_{\mathrm{d}}\right.$ ) and dispersion $\left(\mathrm{QRS}_{\mathrm{D}}\right.$ ), and repolarization (corrected QT interval, $\mathrm{T}_{\text {peak }}-\mathrm{T}_{\text {end }}$, JT and JT $\mathrm{T}_{\text {peak }}$ ), as well as derived indices, were measured. Two hundred dogs met the inclusion/exclusion requirements, including 97 Boxers $(8.1 \pm 2.5$ years old; $30 \pm 7 \mathrm{~kg})$ and 103 non-Boxer $(8.8 \pm 2.5$ years old, $30 \pm 8 \mathrm{~kg}$ ). $\mathrm{QRS}_{\mathrm{d}}$ and $\mathrm{QRS}_{\mathrm{D}}$, and repolarization markers in lead II and left precordial lead V4 were considered similar between groups. Dispersion of late repolarization on lead rV2, Tpeak-Tend interval, was considered longer in Boxers ( $45 \pm 8 \mathrm{~ms}$ vs $38 \pm 10 \mathrm{~ms}, \mathrm{P}=0.01)$. The $\mathrm{T}_{\text {peak }}-\mathrm{T}_{\text {end }} / \mathrm{JT}_{\text {peak }}$ and the $\mathrm{JT}_{\text {peak }} / \mathrm{JT}$ also differed between groups. Our results indicate that the dispersion of myocardial late repolarization in lead rV2 is slower in Boxers than other dog breeds.
\end{abstract}

INDEX TERMS: Electrocardiography, myocardium, conduction, repolarization, Boxer dogs, arrhythmias, canine, electrocardiography, premature cardiac complexes.

RESUMO.- [Marcadores eletrocardiográficos de condução e repolarização miocárdica em cães da raça Boxer.] Marcadores eletrocardiográficos têm sido estudados em seres humanos para estratificação do risco arritmogênico. Os objetivos deste estudo foram investigar os marcadores eletrocardiográficos de condução e repolarização miocárdica em Boxers e em cães de outras raças, e comparar tais resultados entre os grupos. Para tal, a eletrocardiografia convencional de 10 derivações

\footnotetext{
${ }^{1}$ Received on January 16, 2020.

Accepted for publication on January 31, 2020.

${ }^{2}$ Faculdade de Ciências Agrárias e Veterinárias, Universidade Estadual Paulista "Júlio do Mesquita Filho" (Unesp), Via de Acesso Prof. Paulo Donato Castellane s/n, Jaboticabal, SP 14884-900, Brazil. * Corresponding author: beth_rcarvalho@hotmail.com

${ }^{3}$ Laboratório de Cardiologia Comparada, Universidade Federal do Paraná (UFPR), Rua dos Funcionários 1540, Curitiba, PR 80035-050, Brazil.
}

registradas de 2015 a 2018 foram avaliadas de maneira retrospectiva. Cães com idade igual ou superior a 4 anos e pesando $>20 \mathrm{~kg}$ foram incluídos. Animais com insuficiência valvar, cardiopatias congênitas, dilatação cardíaca, suspeita de disfunção sistólica, onda T bifásica, bloqueio(s) de ramo(s), ou aqueles que recebiam antiarrítmicos foram excluídos. Variáveis eletrocardiográficas de condução, como a duração e dispersão do complexo QRS $\left(\mathrm{QRS}_{\mathrm{d}}\right.$ e $\mathrm{QRS} \mathrm{D}_{\mathrm{D}}$, respectivamente), e repolarização (intervalo QT corrigido, $\mathrm{T}_{\text {pico }}-\mathrm{T}_{\text {final }} \mathrm{JT}_{\mathrm{T}} \mathrm{JT} \mathrm{T}_{\text {pico }}$ ), bem como índices derivados, foram mensurados. Duzentos cães que se adequaram aos critérios de inclusão/exclusão foram incluídos, 97 Boxers (8,1 $\pm 2,5$ anos; $30 \pm 7 \mathrm{~kg}$ ) e 103 não Boxers $(8,8 \pm 2,5$ anos; $30 \pm 8 \mathrm{~kg})$. O QRSd e o QRSD, e os marcadores de repolarização nas derivações II e V4 foram similares entre os grupos. 0 marcador de dispersão da repolarização tardia na derivação $\mathrm{rV} 2, \mathrm{~T}_{\text {pico }}-\mathrm{T}_{\text {final, }}$, foi considerado mais longo no 
Boxers ( $45 \pm 8 \mathrm{~ms}$ vs $38 \pm 10 \mathrm{~ms}, \mathrm{P}=0.01) .0 \mathrm{~T}_{\text {pico }}-\mathrm{T}_{\text {final }} / \mathrm{JT}$ pico e o $\mathrm{JT}_{\text {pico }} / \mathrm{JT}$ também diferiram entre os grupos. Nossos resultados indicam que a dispersão da repolarização miocárdica tardia na derivação precordial direita, rV2, é mais lenta no Boxer do que nas outras raças.

TERMOS DE INDEXAÇ̃̃̃O: Eletrocardiografia, condução, repolarização, miocárdio, cães, raça Boxer, arritmias, caninos, eletrocardiografia, complexos cardíacos prematuros.

\section{INTRODUCTION}

Arrhythmogenic right ventricular cardiomyopathy (ARVC) is an inherited myocardial disease commonly seen in adult Boxer dogs. The disease is characterized by the replacement of right ventricle (RV) cardiomyocytes by a fibrofatty tissue, a condition that eventually generates areas prone to the formation of ventricular arrhythmias, which may culminate in sudden death (Harpster 1983,1991). There is no single and specific diagnostic test for ARVC, thus, in veterinary practice, the diagnosis is best based on a combination of findings which may include: the presence of ventricular tachyarrhythmia with no other documented causes for the arrhythmia, syncope, and family history of ARVC (Meurs 2004, 2017). Although many Boxers with ARVC live for years even without treatment, they are always at an increased risk of sudden cardiac death (Meurs 2017).

In people many electrocardiographic markers have been studied to identify individuals at risk for malignant arrhythmias and sudden death (Kurl et al. 2012, Kurosaki et al. 2013, Tse \& Yan 2016, Zumhagen et al. 2016). These can be based on myocardial conduction, such as QRS duration $\left.\left(Q_{R}\right)_{d}\right)$, which is a surrogate marker of conduction velocity $(\mathrm{CV})$, and $\mathrm{QRS}$ dispersion $\left(\mathrm{QRS}_{\mathrm{D}}\right)$ reflecting $\mathrm{CV}$ dispersion. Conduction abnormalities associated with reduced $\mathrm{CV}$, along with a functional or structural obstacle, are conditions for re-entry (Tse \& Yan 2016).

Abnormal repolarization properties can increase the risk of triggered activity and re-entrant arrhythmias, the latter known to be involved in the pathogenesis of ARVC (Basso et al. 2015). Electrocardiographic markers based on repolarization include: corrected QT (QT $)$, QT dispersion $\left(\mathrm{QT}_{\mathrm{D}}\right)$, interval from the peak to the end of the T-wave $\left(\mathrm{T}_{\text {peak }}{ }^{-}\right.$ $\mathrm{T}_{\text {end }}$ ), and interval from J point to the peak and/or end of the $\mathrm{T}_{\text {-wave }}^{\text {end }} \mathrm{T}_{\text {peak }}$ and JT, respectively).

Although studied in many conditions known to be associated with increased arrhythmogenicity in man, such as ARVC (Zorzi et al. 2013), diabetes (Stettler et al. 2007), sepsis (Ozdemir et al. 2016), and myocardial infarction (Zhao et al. 2012), studies investigating electrocardiographic markers of conduction and repolarization in dogs are lacking. The aims of this study were to investigate electrocardiographic markers of conduction and repolarization in Boxers and non-Boxer dogs over $20 \mathrm{~kg}$, and compare such findings between the general population and a breed widely known to be predisposed to developing ventricular arrhythmias.

\section{MATERIALS AND METHODS}

Study Design and Ethics Statement. This retrospective study was approved by the institutional Animal Care and Use Committee (protocol 012277/17).
Animals. Boxer dogs (BG) evaluated from 2015 to 2018 at the Cardiology sections of two referral teaching practices were identified by searching the medical record databases. Only dogs that met the following inclusion criteria were admitted into the study: $\geq 4$ years old, body weight $>20 \mathrm{~kg}$, with a standard high-quality 10 -lead electrocardiogram and an echocardiogram. The electrocardiograms (ECG) (ECGPCVet, Tecnologia Eletrônica Brasileira) were recorded for a minimum of 3 minutes with the animal positioned in right lateral recumbency. The electrodes for frontal and precordial leads were placed as described elsewhere (Tilley \& Burtinick 1999). The echocardiogram (My Lab 30, Esaote) was obtained within a maximum of seven days from the evaluated ECG. Dogs found to have valvular insufficiencies, suspected systolic dysfunction (defined as shortening fraction $\leq 25 \%$ ), left atrial dilation (defined as left atrial-to-aortic root ratio $\geq 1.6$ (Hansson et al. 2002), ventricular dilation (defined as body weight normalized left ventricular internal diameter in diastole $\geq 1.7$ (Cornell et al. 2004), congenital cardiopathies, biphasic T-wave, QRS complexes with bundle branch block morphology, and those receiving antiarrhythmics were excluded. In addition, matched non-Boxer dogs (NBG) were selected based on the same inclusion/ exclusion requirements.

In BG 37 dogs had an available 24-Hour Holter monitoring recorded within seven days of the evaluated ECG and echocardiogram. Boxers were further classified according to the degree of ventricular ectopy, based on the following criteria: 0 to 20 ventricular premature complexes (VPCs) per 24 hours were interpreted as normal; 21 to 300 VPCs per 24 hours were interpreted as indeterminate; and animals with more than $300 \mathrm{VPCs} / 24 \mathrm{~h}$ were considered likely to be affected by ARVC (Meurs 2017). Only the subgroup of Boxers considered normal $(\mathrm{n}=14)$ and the subgroup considered likely to be affected by ARVC $(n=15)$ utilizing the Holter criteria were compared for all electrocardiographic parameters listed in Table 1. The subgroup considered indeterminate $(n=8)$ was excluded from such comparisons.

The clinical history of syncope at the time of ECG and echocardiogram was searched in medical records of all dogs in BG and NBG. In NBG no animal had a recorded syncope, 88 Boxers in BG were unaffected but nine had suffered at least one syncopal episode. All electrocardiographic parameters listed in Table 1 were also compared for syncopal and non-syncopal Boxers.

Electrocardiographic evaluation. One investigator, who was blinded to the breed and clinical status of dogs, measured all the parameters listed in Table 1 and illustrated in Figure 1. The measurements were made in a run of five sequential sinus beats. The highest and lowest values obtained for each parameter were excluded and the final result was considered as the average of three measurements. Parameters obtained from precordial leads were measured using leads $\mathrm{rV} 2$ as right and $\mathrm{V} 4$ as left.

Statistical analysis. The Shapiro-Wilk test was used to investigate the normal distribution of data. Groups were compared using either Mann-Whitney test or Student's t-test according to distribution. Parametric data are represented as mean \pm standard deviation, while non-parametric variables are shown as median [interquartile range]. The contingency was evaluated using the Fisher's exact test. Statistical processing was performed using commercially available statistical software (Prism Windows 6.0, GraphPad Software), and significance was defined as $\mathrm{P}<0.05$.

\section{RESULTS}

A total of 200 dogs met the inclusion/exclusion requirements and were recruited for this study. The sample comprised 97 
Boxers and 103 non-Boxer dogs. No differences in gender were documented within or between groups. The mean body weight did not differ between groups (Boxers $30 \pm 7 \mathrm{~kg}$, nonBoxers $30 \pm 8 \mathrm{~kg}, \mathrm{P}=0.82$ ). The mean age was also considered similar between groups (Boxers $8.1 \pm 2.5$ years old, non-Boxers $8.8 \pm 2.5$ years old, $\mathrm{P}=0.16$ ). Among NBG, mixed breed dogs were most represented ( $\mathrm{n}=67,65 \%)$, followed by Labrador Retrievers ( $\mathrm{n}=11,11 \%)$, Pitbulls ( $\mathrm{n}=9,9 \%)$, and Golden Retrievers $(n=8,8 \%)$. No animal from NBG had a history of syncope. In BG, nine dogs (9\%) had a clinical history of syncope, and 88 (91\%) had no previous history.

The electrocardiographic markers of conduction, $\mathrm{QRS}_{\mathrm{d}}$ and $\mathrm{QRS}_{\mathrm{D}}$, were considered similar between $\mathrm{BG}$ and $\mathrm{NBG}$. Also, no differences existed between $B G$ and NBG regarding

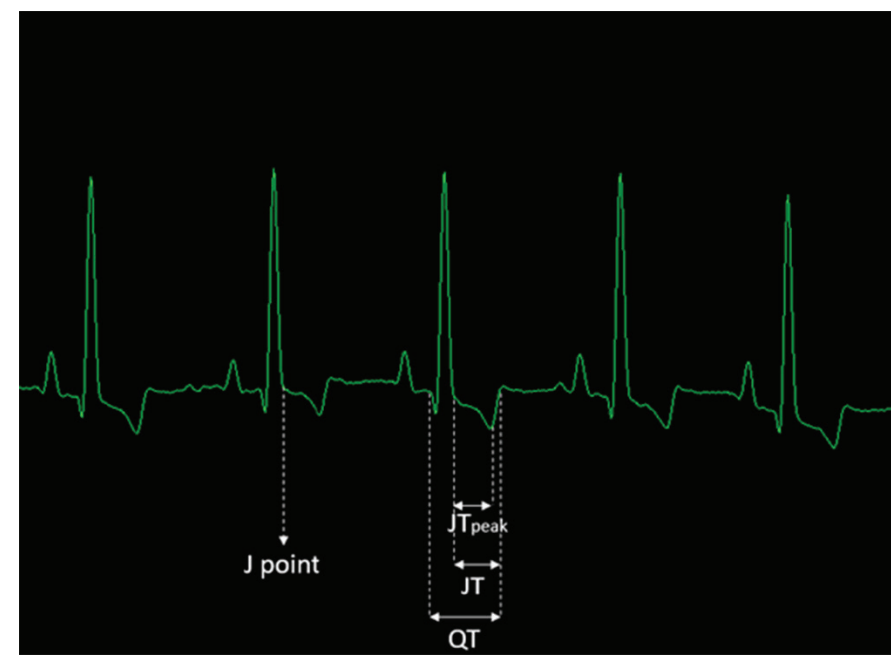

Fig.1. Schematic representation of J point, QT interval, JT interval and $\mathrm{JT}_{\text {peak }}$ interval measurements used to obtain electrocardiographic markers in lead II. the myocardial repolarization markers obtained from leads II and V4. When looking at lead rV2, the dispersion of late repolarization evaluated as $T_{\text {peak }}-T_{\text {end }}$ was longer in Boxers $(45 \pm 8 \mathrm{~ms})$ than it was in non-Boxer dogs $(38 \pm 10 \mathrm{~ms})(\mathrm{P}=0.01)$. Similarly, the dispersion of repolarization normalized to $\mathrm{JT}_{\text {peak }}$ interval obtained from lead rV2, i.e. $\mathrm{T}_{\text {peak }}-\mathrm{T}_{\text {end }} / \mathrm{JT} \mathrm{T}_{\text {peak }}$ was found to be higher in BG $(0.41$ [0.35-0.51]) than in NBG (0.37 [0.27-0.40]) $(\mathrm{P}=0.03)$. Curiously, the dispersion of repolarization normalized to $\mathrm{JT}$ interval, the $\mathrm{JT}_{\text {peak }} / \mathrm{JT}$, was found to be slightly lower in Boxers (0.72 [0.67-0.75] vs 0.73 [0.71-0.79], $\mathrm{P}=0.04$ ). Our results are summarized in Table 2 , and box-plots of markers found to be different between groups are represented in Figure 2.

Interestingly, no differences were documented in the electrocardiographic markers between syncopal and nonsyncopal Boxers (Table 3), or between Boxers considered normal $(n=12)$ and those likely affected by ARVC $(n=15)$ according to the 24-Hour Holter criteria for the degree of ventricular ectopy (Table 4).

\section{DISCUSSION}

In this study, traditional and novel electrocardiographic conduction and repolarization markers of augmented arrhythmogenesis were evaluated and compared between Boxers and dogs of other breeds. In these retrospective analyses, both Boxers who had history of syncope $(n=9)$ and those without $(\mathrm{n}=88)$ were included, as well as Boxers considered normal $(n=12)$ or likely affected by ARVC $(n=15)$ according to Holter criteria. None of the dogs had received antiarrhythmic therapy at the time the electrocardiogram was recorded. The body weight and age were considered similar between BG and NBG, although only animals $\geq 4$ years old and $>20 \mathrm{~kg}$ were included in the study to minimize the impact of the dog's size and age on electrocardiographic parameters.

Table 1. Summary of electrocardiographic markers evaluated in this study, which are based on either myocardial conduction or repolarization

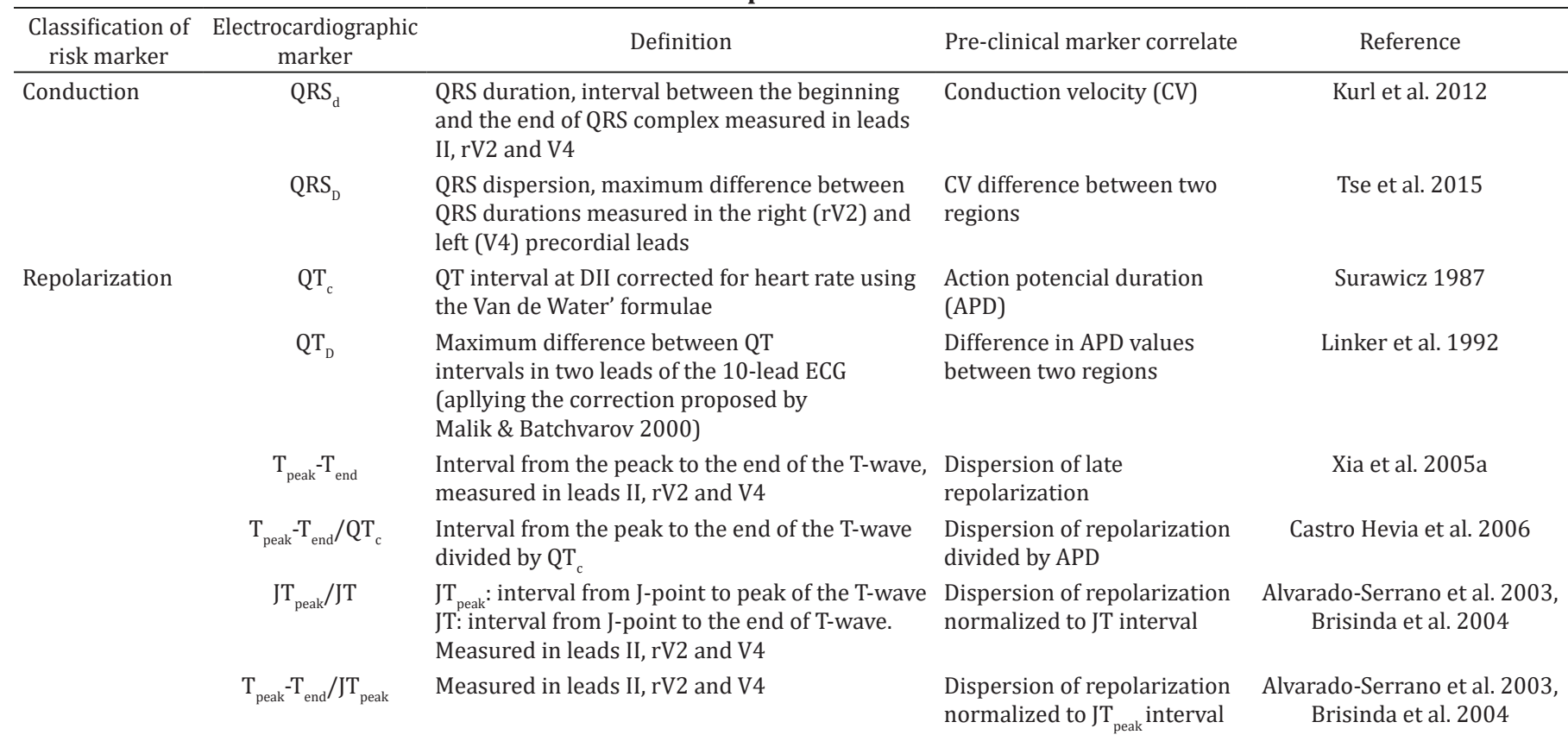


The pathological features of ARVC in both people and Boxer dogs, which are considered as a spontaneous animal model for the study of the human ARVC, include cardiomyocyte atrophy and fibrofatty replacement (Marcus et al. 1982, Basso et al. 2015). Depolarization delay in right precordial leads is a common feature in people with ARVC (Nasir et al. 2004, Cox et al. 2008). Thus, the QRS prolongation ( $>110 \mathrm{~ms}$ ) in right precordial leads is considered a major criteria for diagnosis of ARVC in people (Marcus et al. 2010), and an independent predictor of risk of sudden cardiac death in the general population (Kurl et al. 2012). However, our findings suggest that the electrocardiographic surrogates of conduction velocity of myocardial depolarization impulse behave similarly in Boxers and in medium to large non-Boxer dogs, and Boxers with a high degree of ventricular ectopy ( $>300 \mathrm{VPCs} / 24 \mathrm{~h}$ ) compared to those with a low number of VPCs (0-20 VPCs/24h).

The QT interval reflects the duration of the action potential at the cellular level, being associated with depolarization and triggered activity. The QT interval in people with type 1 diabetes is considered an independent predictor of cardiovascular mortality (Stettler et al. 2007). However, although it is a poor indicator of heterogeneity in repolarization across the heart, it is known that increased heterogeneities in repolarization increase the risk of arrhythmias (Tse \& Yan 2016). No

Table 2. Comparison of electrocardiographic surrogates of myocardial conduction and repolarization in Boxer dogs (n=97) and non-Boxer dogs $(n=103)$ obtained from the 10-lead standard electrocardiography

\begin{tabular}{|c|c|c|c|c|}
\hline Electrocardiographic marker & Boxer & non-Boxer & $\mathrm{P}$ & Pre-clinical marker correlate \\
\hline $\mathrm{QRS}_{\mathrm{d}}$ lead II & $67(61-76) \mathrm{ms}$ & $60(57-67) \mathrm{ms}$ & 0.06 & Conduction velocity (CV) \\
\hline $\mathrm{QRS}_{\mathrm{d}}$ lead rV2 & $70(67-77) \mathrm{ms}$ & $67(60-73) \mathrm{ms}$ & 0.11 & \\
\hline $\mathrm{QRS}_{\mathrm{d}}$ lead V4 & $64 \pm 9 \mathrm{~ms}$ & $64 \pm 10 \mathrm{~ms}$ & 0.89 & \\
\hline $\mathrm{QT}_{\mathrm{c}}$ & $257(246-272) \mathrm{ms}$ & $254(242-258) \mathrm{ms}$ & 0.22 & Action potencial duration (APD) \\
\hline $\mathrm{QT}_{\mathrm{D}}$ & $7(5-11) \mathrm{ms}$ & $7(5-8) \mathrm{ms}$ & 0.54 & Difference in APD values between two regions \\
\hline $\mathrm{T}_{\text {peak }}-\mathrm{T}_{\text {end }}$ lead V4 & $35 \pm 9 \mathrm{~ms}$ & $34 \pm 12 \mathrm{~ms}$ & 0.51 & \\
\hline $\mathrm{T}_{\text {peak }}-\mathrm{T}_{\text {end }} / \mathrm{QT}_{\mathrm{c}}$ lead II & $0.14 \pm 0.04$ & $0.12 \pm 0.03$ & 0.34 & Dispersion of repolarization divided by APD \\
\hline $\mathrm{T}_{\text {peak }}-\mathrm{T}_{\text {end }} / \mathrm{QT}_{\mathrm{c}}$ lead rV2 & $0.17(0.15-0.19)$ & $0.15(0.13-0.18)$ & 0.07 & \\
\hline $\mathrm{T}_{\text {peak }}-\mathrm{T}_{\text {end }} / \mathrm{QT} \mathrm{T}_{\mathrm{c}}$ lead V4 & $0.13(0.11-0.16)$ & $0.12(0.09-0.17)$ & 0.67 & \\
\hline JT DII & $146 \pm 22 \mathrm{~ms}$ & $150 \pm 10 \mathrm{~ms}$ & 0.47 & Global dispersion of repolarization \\
\hline $\mathrm{JT}_{\text {peak }} \mathrm{rV} 2$ & $105 \pm 18 \mathrm{~ms}$ & $110 \pm 7 \mathrm{~ms}$ & 0.29 & \\
\hline $\mathrm{JT}_{\text {peak }} \mathrm{V} 4$ & $119 \pm 20 \mathrm{~ms}$ & $117 \pm 14 \mathrm{~ms}$ & 0.78 & \\
\hline $\mathrm{JT}_{\text {peak }} / \mathrm{JT}$ lead II & $0.76(0.71-0.83)$ & $0.82(0.76-0.86)$ & 0.08 & Dispersion of repolarization normalized to JT interval \\
\hline $\mathrm{JT}_{\text {peak }} / \mathrm{JT}$ lead rV2 & $0.72(0.67-0.75)$ & $0.73(0.71-0.79)$ & $0.04^{*}$ & \\
\hline $\mathrm{JT}_{\text {peak }} / \mathrm{JT}$ lead V4 & $0.78(0.73-0.81)$ & $0.77(0.73-0.83)$ & 0.64 & \\
\hline $\mathrm{T}_{\text {peak }}-\mathrm{T}_{\text {end }} / \mathrm{JT}_{\text {peak }}$ lead II & $0.33(0.23-0.42)$ & $0.26(0.19-0.29)$ & 0.08 & Dispersion of repolarization normalized to $\mathrm{JT}_{\text {peak }}$ interval \\
\hline $\mathrm{T}_{\text {peak }}-\mathrm{T}_{\text {end }} / \mathrm{JT}_{\text {peak }}$ lead rV2 & $0.41(0.35-0.51)$ & $0.37(0.27-0.40)$ & $0.03^{*}$ & \\
\hline $\mathrm{T}_{\text {peak }}-\mathrm{T}_{\text {end }} / \mathrm{JT}_{\text {peak }}$ lead V4 & $0.29(0.25-0.37)$ & $0.27(0.18-0.40)$ & 0.50 & \\
\hline
\end{tabular}

* Statistical significance $(\mathrm{P}<0.05)$.

Tpeak-Tend - lead rV2(ms)

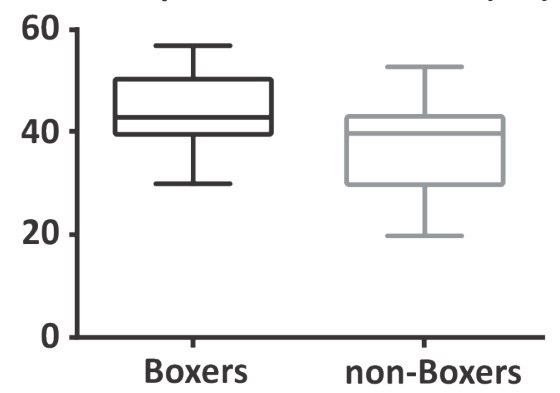

Tpeak-Tend/JTpeak - lead rV2

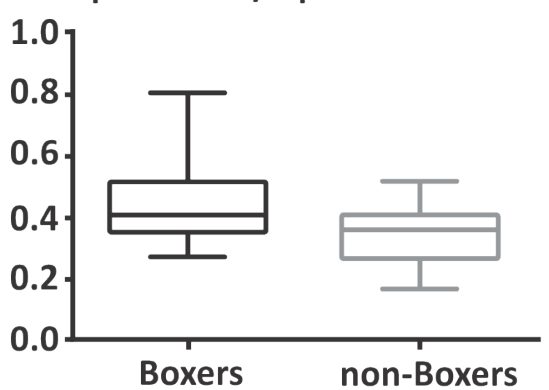

JTpeak/JT - lead rV2

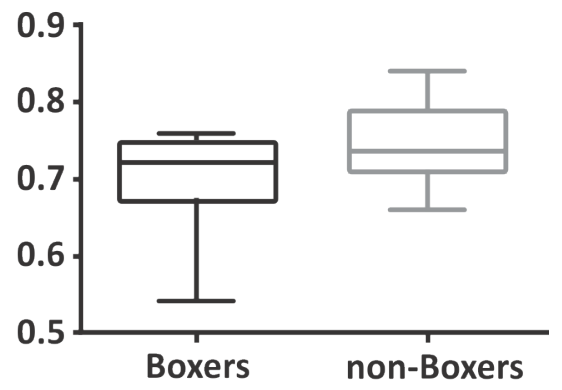

\section{R}

Fig.2. Box-plots of data distribution for electrocardiographic markers of repolarization found to differ between Boxer (n=97) and nonBoxer $(n=103)$ dogs. 
differences were noticed either in $\mathrm{QT}_{\mathrm{c}}$ or $\mathrm{QT}_{\mathrm{D}}$ between groups in this investigation.

The fibrofatty tissue that replaces healthy myocardium in ARVC is thought to contribute to the development of ventricular arrhythmias by slowing intra-ventricular conduction, and acting as a substrate for arrhythmias through a scar-related macro-reentry mechanism (Fontaine et al. 1984). The $\mathrm{T}_{\text {peak }}-\mathrm{T}_{\text {end }}$ interval is important as a lead-dependent marker of global dispersion of late repolarization (Xia et al. 2005a, 2005b), since repolarization dispersion varies in different cardiac regions (Bieganowska et al. 2013). Therefore, it was proposed that $\mathrm{T}_{\text {peak }}-\mathrm{T}_{\text {end }}$ interval should be determined from right precordial leads for right ventricular disorders (Tse \& Yan 2016). When the right precordial lead rV2 is considered, our results for the electrocardiographic markers $\mathrm{T}_{\text {peak }}-\mathrm{T}_{\text {end }}$ and $\mathrm{T}_{\text {peak }}-\mathrm{T}_{\text {end }} / \mathrm{JT}$ peak suggest that the late dispersion of $\mathrm{RV}$ repolarization occurs more slowly in Boxer dogs than in other breeds. In people $\mathrm{T}_{\text {park }}-\mathrm{T}_{\text {end }}$ is increased in short QT syndrome (Watanabe et al. 2010), Brugada syndrome (Zumhagen et al. 2016), and patients with "torsade des pointes" (Yamaguchi et al. 2003).

While $\mathrm{T}_{\text {peak }}-\mathrm{T}_{\text {end }}$ represents late repolarization, $\mathrm{JT}_{\text {peak }}$ represents early repolarization (Johannesen et al. 2014a, 2014b), and both are potential markers of abnormal repolarization (Clemente et al. 2012). In people, the JT $\mathrm{T}_{\text {peak }} / \mathrm{JT}$ and the $\mathrm{T}_{\text {peak }}{ }^{-}$ $\mathrm{T}_{\text {end }} / \mathrm{JT}_{\text {peak }}$ showed a higher sensitivity and specificity than $\mathrm{T}_{\text {peak }}^{\text {end }} \mathrm{T}_{\text {end }}$ for identifying patients who suffered myocardial infarction (Alvarado-Serrano et al. 2006). The dispersion of repolarization normalized to $\mathrm{JT}$ or $\mathrm{JT}_{\text {peak }}$ interval at rV2 differs in Boxers form non-Boxers in our study. Unexpectedly, the marker $\mathrm{JT}_{\text {peak }} / \mathrm{JT}$ was slightly lower in $\mathrm{BG}$, mainly due to the interquartile range difference between groups, since median values were similar in both groups.

The small and unequal sample size between syncopal and non-syncopal Boxers may have contributed significantly

Table 3. Comparison of electrocardiographic surrogates of myocardial conduction and repolarization in syncopal $(n=9)$ and non-syncopal Boxer dogs $(n=88)$ obtained from 10-lead standard electrocardiography

\begin{tabular}{|c|c|c|c|}
\hline $\begin{array}{l}\text { Electrocardiographic } \\
\text { marker }\end{array}$ & $\begin{array}{c}\text { Non-syncopal } \\
(\mathrm{n}=88)\end{array}$ & Syncopal (n=9) & $p$ \\
\hline $\mathrm{QRS}_{\mathrm{d}}$ lead II & $63(60-70) \mathrm{ms}$ & $73(63-80) \mathrm{ms}$ & 0.11 \\
\hline $\mathrm{QRS}_{\mathrm{d}}$ lead rV2 & $67(63-73) \mathrm{ms}$ & $73(67-80) \mathrm{ms}$ & 0.14 \\
\hline $\mathrm{QRS}_{\mathrm{d}}$ lead V4 & $64 \pm 8 \mathrm{~ms}$ & $63 \pm 8 \mathrm{~ms}$ & 0.60 \\
\hline $\mathrm{QRS}_{\mathrm{D}}$ & $6(3-13) \mathrm{ms}$ & $10(6-17) \mathrm{ms}$ & 0.21 \\
\hline $\mathrm{QT}_{\mathrm{c}}$ & $257 \pm 16 \mathrm{~ms}$ & $267 \pm 28 \mathrm{~ms}$ & 0.19 \\
\hline $\mathrm{QT}_{\mathrm{D}}$ & $5(4-10) \mathrm{ms}$ & $7(5-11) \mathrm{ms}$ & 0.26 \\
\hline $\mathrm{T}_{\text {peak }}-\mathrm{T}_{\text {end }}$ lead II & $31 \pm 10 \mathrm{~ms}$ & $35 \pm 9 \mathrm{~ms}$ & 0.26 \\
\hline $\mathrm{T}_{\text {peak }}-\mathrm{T}_{\text {end }}$ lead rV2 & $43(38-53) \mathrm{ms}$ & $50(37-50) \mathrm{ms}$ & 0.77 \\
\hline $\mathrm{T}_{\text {peak }}-\mathrm{T}_{\text {end }}$ lead V4 & $37 \pm 11 \mathrm{~ms}$ & $33 \pm 9 \mathrm{~ms}$ & 0.34 \\
\hline $\mathrm{T}_{\text {peak }}-\mathrm{T}_{\text {end }} / \mathrm{QT}$ c lead II & $0.12 \pm 0.04$ & $0.13 \pm 0.04$ & 0.38 \\
\hline $\mathrm{T}_{\text {peak }}-\mathrm{T}_{\text {end }} / \mathrm{QT}_{\mathrm{c}}$ lead rV2 & $0.16(0.15-0.20)$ & $0.18(0.16-0.19)$ & 0.83 \\
\hline $\mathrm{T}_{\text {peak }}-\mathrm{T}_{\text {end }} / \mathrm{QT}_{c}$ lead V4 & $0.14 \pm 0.05$ & $0.12 \pm 0.05$ & 0.13 \\
\hline $\mathrm{JT}_{\text {peak }} / \mathrm{JT}$ lead II & $0.79(0.73-0.85)$ & $0.75(0.73-0.82)$ & 0.24 \\
\hline $\mathrm{JT}_{\text {peak }} / \mathrm{JT}$ lead rV2 & $0.72(0.70-0.75)$ & $0.71(0.65-0.73)$ & 0.14 \\
\hline $\mathrm{JT}_{\text {peak }} / \mathrm{JT}$ lead V4 & $0.77 \pm 0.06$ & $0.78 \pm 0.07$ & 0.52 \\
\hline $\mathrm{T}_{\text {peak }}-\mathrm{T}_{\text {end }} / \mathrm{JT}$ peak lead II & $0.26(0.20-0.36)$ & $0.34(0.24-0.40)$ & 0.21 \\
\hline $\mathrm{T}_{\text {peak }}-\mathrm{T}_{\text {end }} / \mathrm{JT}$ peak lead rV2 & $0.38(0.34-0.47)$ & $0.44(0.38-0.52)$ & 0.30 \\
\hline $\mathrm{T}_{\text {peak }}-\mathrm{T}_{\text {end }} / \mathrm{JT} \mathrm{T}_{\text {peak }}$ lead $\mathrm{V} 4$ & $0.29(0.25-0.37)$ & $0.28(0.20-0.34)$ & 0.57 \\
\hline
\end{tabular}

to our findings in such a comparison. According to our results, myocardial conduction and repolarization is similar in supposedly healthy and syncopal Boxers. As previously mentioned, a diagnosis of ARVC in veterinary patients is based on a combination of findings, including ventricular arrhythmias, syncope, and familial history of ARVC. Many disorders, such as neurocardiogenic bradycardia (Thomason et al. 2008), can ultimately lead to syncopal events. Antiarrhythmic drugs such as sotalol and mexiletine act by blocking ion channels, potassium and sodium respectively, in the cellular membrane, thus, interfering in electrocardiographic measurements, especially those related to conduction and repolarization. Since most syncopal Boxers admitted to a referring cardiology service are already receiving antiarrhythmic therapy, it is challenging to study electrocardiographic markers in such individuals.

The results of this study should be interpreted in the context of its limitations. This was a retrospective investigation and accepts the inherent criticisms of the methodology. Moreover, it is difficult to determine the end of the T-wave on conventional electrocardiography, as previously reported by many researchers and this may introduce inaccuracies (Bieganowska et al. 2013, Kaplan et al. 2015, Tse \& Yan 2016, Zumhagen et al. 2016). Also, the low number of syncopal Boxers, and those with a 24-hour Holter recording may have compromised the accuracy of our analysis.

\section{CONCLUSIONS}

Myocardial electrical conduction occurs similarly in Boxer dogs and non-Boxer dogs.

Global dispersion of myocardial late repolarization in the right precordial lead rV2 occurs more slowly in Boxers than dogs from other breeds.

Table 4. Comparison of electrocardiographic surrogates of myocardial conduction and repolarization obtained from 10lead standard electrocardiography in Boxer dogs considered normal $(n=12)$ and affected by ARVC $(n=15)$ according to the degree of ventricular ectopy on 24-hour Holter monitoring

\begin{tabular}{|c|c|c|c|}
\hline $\begin{array}{c}\text { Electrocardiographic } \\
\text { marker }\end{array}$ & $\begin{array}{c}\text { Normal Boxers } \\
(n=12)\end{array}$ & $\begin{array}{c}\text { ARVC Boxers } \\
(\mathrm{n}=15)\end{array}$ & $\mathrm{P}$ \\
\hline $\mathrm{QRS}_{\mathrm{d}}$ lead II & $63(60-67) \mathrm{ms}$ & $73(63-80) \mathrm{ms}$ & 0.05 \\
\hline $\mathrm{QRS}_{\mathrm{d}}$ lead rV2 & $69 \pm 7 \mathrm{~ms}$ & $72 \pm 7 \mathrm{~ms}$ & 0.15 \\
\hline $\mathrm{QRS}_{\mathrm{d}}$ lead V4 & $67(60-70) \mathrm{ms}$ & $63(57-70) \mathrm{ms}$ & 0.48 \\
\hline $\mathrm{QRS}_{\mathrm{D}}$ & $8 \pm 9 \mathrm{~ms}$ & $9 \pm 6 \mathrm{~ms}$ & 0.37 \\
\hline $\mathrm{QT}_{\mathrm{c}}$ & $260 \pm 15 \mathrm{~ms}$ & $267 \pm 28 \mathrm{~ms}$ & 0.40 \\
\hline $\mathrm{QT}_{\mathrm{D}}$ & $5(4-11) \mathrm{ms}$ & $7(5-11) \mathrm{ms}$ & 0.25 \\
\hline $\mathrm{T}_{\text {peak }}-\mathrm{T}_{\text {end }}$ lead II & $32 \pm 10 \mathrm{~ms}$ & $35 \pm 9 \mathrm{~ms}$ & 0.33 \\
\hline $\mathrm{T}_{\text {peak }}-\mathrm{T}_{\text {end }}$ lead rV2 & $43(37-54) \mathrm{ms}$ & $50(37-50) \mathrm{ms}$ & 0.99 \\
\hline $\mathrm{T}_{\text {peak }}-\mathrm{T}_{\text {end }}$ lead V4 & $39 \pm 12 \mathrm{~ms}$ & $33 \pm 9 \mathrm{~ms}$ & 0.14 \\
\hline $\mathrm{T}_{\text {peak }}-\mathrm{T}_{\text {end }} / \mathrm{QT}$ c lead II & $0.13 \pm 0.04$ & $0.13 \pm 0.04$ & 0.45 \\
\hline $\mathrm{T}_{\text {peak }}-\mathrm{T}_{\text {end }} / \mathrm{QT}_{\mathrm{c}}$ lead rV2 & $0.16(0.15-0.19)$ & $0.18(0.16-0.19)$ & 0.79 \\
\hline $\mathrm{T}_{\text {peak }}-\mathrm{T}_{\text {end }} / \mathrm{QT}$ c lead V4 & $0.15 \pm 0.05$ & $0.12 \pm 0.05$ & 0.07 \\
\hline $\mathrm{JT}_{\text {peak }} / \mathrm{JT}$ lead II & $0.78(0.72-0.87)$ & $0.75(0.73-0.82)$ & 0.38 \\
\hline $\mathrm{JT}_{\text {peak }} / \mathrm{JT}$ lead rV2 & $0.73(0.69-0.75)$ & $0.71(0.65-0.73)$ & 0.21 \\
\hline $\mathrm{JT}_{\text {peak }} / \mathrm{JT}$ lead V4 & $0.76 \pm 0.07$ & $0.79 \pm 0.06$ & 0.36 \\
\hline $\mathrm{T}_{\text {peak }}-\mathrm{T}_{\text {end }} / \mathrm{JT} \mathrm{T}_{\text {peak }}$ lead II & $0.24(0.19-0.37)$ & $0.34(0.24-0.40)$ & 0.23 \\
\hline $\mathrm{T}_{\text {peak }}-\mathrm{T}_{\text {end }} / \mathrm{JT}_{\text {peak }}$ lead rV2 & $0.43 \pm 0.15$ & $0.45 \pm 0.10$ & 0.30 \\
\hline $\mathrm{T}_{\text {peak }}-\mathrm{T}_{\text {end }} / \mathrm{JT}$ peak lead $\mathrm{V} 4$ & $0.34 \pm 0.15$ & $0.29 \pm 0.11$ & 0.27 \\
\hline
\end{tabular}


Traditional and novel electrocardiographic markers of myocardial conduction and repolarization were obtained in Boxers and non-Boxers dogs $>20 \mathrm{~kg}$.

Acknowledgements.- Authors acknowledge the "Coordenação de Aperfeiçoamento de Pessoal de Nível Superior” (CAPES), Brazil, for funding the research.

Conflict of interest statement.- The authors have no competing interests.

\section{REFERENCES}

Alvarado-Serrano C., Ramos-Castro J. \& Pallas-Areny R. 2003. Do ventricular repolarization interval ratios depend on heart rate and should they be rate-corrected? Engineering in Medicine and Biology Society Proceedings of the 25th Annual International Conference of the IEEE, 51:59 -61. <http://dx.doi.org/10.1109/IEMBS.2003.1279507>

Alvarado-Serrano C., Ramos-Castro J. \& Pallàs-Areny R. 2006. Novel indices of ventricular repolarization to screen post myocardial infarction patients. Comput. Biol. Med. 36(5):507-515. <http://dx.doi.org/10.1016/j. compbiomed.2005.03.003><PMid:15899477>

Basso C., Fox P.R. \& Meurs K.M. 2015. Arrhythmogenic right ventricular cardiomyopathy causing sudden cardiac death in boxer dogs a new animal model of human disease. Circulation 109(9):1180-1185. <http://dx.doi. org/10.1161/01.CIR.0000118494.07530.65> <PMid:14993138>

Bieganowska K., Sawicka-Parobczyk M., Bieganowski M. \& Piskorski J. 2013. $\mathrm{T}_{\text {peak }}-\mathrm{T}_{\text {end }}$ interval in 12-lead electrocardiogram of healthy children and adolescents $\mathrm{T}_{\text {peak }}-\mathrm{T}_{\text {end }}$ interval in childhood. Ann. Noninvasive Electrocardiol. 18(4):344-351.

Brisinda D., Meloni A.M. \& Fenici R. 2004. Magnetocardiographic study of ventricular repolarization in hypertensive patients with and without left ventricular hypertrophy. Neurol. Clin. Neurophysiol. 2004:13. <PMid: 6012643>

Castro Hevia J., Antzelevitch C., Tornes Barzaga F., Dorantes Sanchez M., Dorticos Balea F. \& Zayas Molina R. 2006. Tpeak-Tend and Tpeak-Tend dispersion as risk factors for ventricular tachycardia/ventricular fibrillation in patients with the Brugada syndrome. J. Am. Coll. Cardiol. 47(9):1828 -1834. <http://dx.doi.org/10.1016/j.jacc.2005.12.049><PMid:16682308>

Clemente D., Pereira T. \& Ribeiro S. 2012. Repolarização ventricular em pacientes diabéticos: caracterização e implicações clínicas. Arq. Bras. Cardiol. 99(5):1015-1022.<http://dx.doi.org/10.1590/S0066-782X2012005000095>

Cornell C.C., Kittleson M.D. \& Della Torre P. 2004. Allometric scaling of M-mode cardiac measurements in normal adult dogs. J. Vet. Intern. Med. 18(3):311-321. <http://dx.doi.org/10.1892/0891-6640(2004)18<311:as omcm>2.0.co;2><PMid:15188817>

Cox M.G.P.J., Nelen M.R. \& Wilde A.A.M. 2008. Activation delay and VT parameters in arrhythmogenic right ventricular dysplasia/cardiomyopathy: toward improvement of diagnostic ECG criteria. J. Cardiovasc. Electrophysiol. 19(8):775-781. <http://dx.doi.org/10.1111/j.1540-8167.2008.01140.x> $<$ PMid:18373594>

Fontaine G., Frank R. \& Tonet J.L. 1984. Arrhythmogenic right ventricular dysplasia: a clinical model for the study of chronic ventricular tachycardia. Jpn. Circ. J. 48(6):515-538. <http://dx.doi.org/10.1253/jcj.48.515> $<$ PMid:6376841>

Hansson K., Häggström J., Kvart C. \& Lord P. 2002. Left atrial to aortic root indices using two-dimensional and M-mode echocardiography in cavalier King Charles spaniels with and without left atrial enlargement. Vet. Radiol. Ultrasound 43(6):568-575.<http://dx.doi.org/10.1111/j.1740-8261.2002. tb01051.x><PMid:12502113>

Harpster N. 1983. Boxer cardiomyopathy, p.329-337. In: Kirk R. (Ed.), Current Veterinary Therapy VIII. W.B. Saunders, Philadelphia.
Harpster N. 1991. Boxer cardiomyopathy. A review of the long-term benefits of antiarrhythmic therapy. Vet. Clin. N. Am. Small Anim. Pract. 21(5):989-1004. <http://dx.doi.org/10.1016/s0195-5616(91)50107-8><PMid:1949503>

Johannesen L., Vicente J. \& Gray R.A. 2014a. Improving the assessment of heart toxicity for all new drugs through translational regulatory science. Clin. Pharmacol. Ther. 95(5):501-508. <http://dx.doi.org/10.1038/ clpt.2013.238> <PMid:24336137>

Johannesen L., Vicente J. \& Mason J.W. 2014b. Differentiating drug-induced multichannel block on the electrocardiogram: randomized study of dofetilide, quinidine, ranolazine, and verapamil. Clin. Pharmacol. Ther. 96(5):549-558. <http://dx.doi.org/10.1038/clpt.2014.155><PMid:25054430>

Kaplan O., Kurtoglu E. \& Nar G. 2015. Avaliação eletrocardiográfica do intervalo $\mathrm{T}_{\text {peak }}-\mathrm{T}_{\text {end }}$ em indivíduos com espessura aumentada do tecido adiposo epicárdico. Arq. Bras. Cardiol. 105(6):566-572. <http://dx.doi org/10.5935/abc.20150124>

Kurl S., Makikallio T.H. \& Rautaharju P. 2012. Duration of QRS complex in resting electrocardiogram is a predictor of sudden cardiac death in men. Circulation 125(21):2588-2594. <http://dx.doi.org/10.1161/ CIRCULATIONAHA.111.025577> <PMid:22615341>

Kurosaki K., Nogami A., Shirai Y. \& Kowase S. 2013. Positive QRS complex in lead I as a malignant sign in right ventricular outflow tract tachycardia. Circ J. 77(4):968-974. <http://dx.doi.org/10.1253/circj.cj-12-0864> <PMid:23238367>

Linker N.J., Colonna P., Kekwick C.A., Till J., Camm A.J., Ward D.E. 1992. Assessment of QT dispersion in symptomatic patients with congenital long QT syndromes. Am. J. Cardiol. 69(6):634-638. <http://dx.doi. org/10.1016/0002-9149(92)90155-r> <PMid:1346947>

Malik M. \& Batchvarov V.N. 2000. Measurement, interpretation and clinical potential of QT dispersion. J. Am. Coll. Cardiol. 36(6):1749-1766. <http://dx.doi.org/10.1016/s0735-1097(00)00962-1><PMid:11092641>

Marcus F.I., Fontaine G.H., Guiraudon G. \& Al E. 1982. Right ventricular dysplasia: a report of 24 adult cases. Circulation 65(2):384-398. <http://dx.doi.org/10.1161/01.cir.65.2.384> <PMid:7053899>

Marcus F.I., McKenna W.J., Sherrill D., Basso C., Bauce B., Bluemke D.A., Calkins H., Corrado D., Cox M.GP.J., Daubert J.P., Fontaine G., Gear K., Hauer R., Nava A., Picard M.H., Protonotarios N., Saffitz J.E., Sanborn D.M.Y., Steinberg J.S., Tandri H., Thiene G., Towbin J.A., Tsatsopoulou A., Wichter T. \& Zareba W. 2010. Diagnosis of arrhythmogenic right ventricular cardiomyopathy/ dysplasia: proposed modification of the Task Force Criteria. Eur. Heart J. 31(7):806-814. <http://dx.doi.org/10.1093/eurheartj/ehq025> <PMid:20172912>

Meurs K.M. 2004. Boxer dog cardiomyopathy: an update. Vet. Clin. N. Am., Small Anim. Pract. 34(5):1235-1244. <http://dx.doi.org/10.1016/j. cvsm.2004.05.003><PMid:15325480>

Meurs K.M. 2017. Arrhythmogenic right ventricular cardiomyopathy in the boxer dog: an update. Vet. Clin. N. Am., Small Anim. Pract. 47(5):1103-1111. <http://dx.doi.org/10.1016/j.cvsm.2017.04.007> <PMid:28647112>

Nasir K., Bomma C. \& Tandri H. 2004. Electrocardiographic features of arrhythmogenic right ventricular dysplasia/cardiomyopathy according to disease severity: a need to broaden diagnostic criteria. Circulation 110(12):1527-1534. <http://dx.doi.org/10.1161/01.CIR.0000142293.60725.18> $<$ PMid:15381658>

Ozdemir R., Isguder R. \& Kucuk M. 2016. A Valuable tool in predicting poor outcome due to sepsis in pediatric intensive care unit: Tp-e/QT Ratio. J. Trop. Pediatr. 62(5):377-384. <http://dx.doi.org/10.1093/tropej/fmw021> $<$ PMid:27085180>

Stettler S., Bearth A., Allemann S. \& Al E. 2007. QTc interval and resting heart rate as long-term predictors of mortality in type 1 and type 2 diabetes mellitus: a 23-year follow-up. Diabetologia 50(1):186-194. <http://dx.doi. org/10.1007/s00125-006-0483-1><PMid:17096116> 
Surawicz B. 1987. The QT interval and cardiac arrhythmias. Annu. Rev. Med. 38 (1): 81-90.<http://dx.doi.org/10.1146/annurev.me.38.020187.000501>

Thomason J.D., Kraus M.S. \& Surdyk K.K. 2008. Bradycardia-associated syncope in 7 Boxers with ventricular tachycardia (2002-2005). J. Vet. Intern. Med. 22(4):931-936. <http://dx.doi.org/10.1111/j.1939-1676.2008.0119.x> $<$ PMid:18537877>

Tilley L.P. \& Burtinick N.L. 1999. Electrocardiography for the Small Animal Practitioner. Teton New Media, WY. 106p.

Tse G. \& Yan B.P. 2016. Traditional and novel electrocardiographic conduction and repolarization markers of sudden cardiac death. Europace 19(5):712721. <http://dx.doi.org/10.1093/europace/euw280><PMid:27702850>

Watanabe H., Makiyama T. \& Koyama T. 2010. High prevalence of early repolarization in short QT syndrome. Heart Rhythm 7(5):647-652. <http://dx.doi.org/10.1016/j.hrthm.2010.01.012> <PMid:20206319>

Xia Y., Kongstad O., Liao Q. \& Al E. 2005a. In vivo validation of the coincidence of the peak and end of the $\mathrm{T}$ wave with full repolarization of the epicardium and endocardium in swine. Heart Rhythm 2(2):162-169. <http://dx.doi org/10.1016/j.hrthm.2004.11.011><PMid:15851290>
Xia Y., Liang Y. \& Kongstad O. 2005b. $\mathrm{T}_{\text {peak }}-\mathrm{T}_{\text {end }}$ interval as an index of global dispersion of ventricular repolarization: evaluations using monophasic action potential mapping of the epi- and endocardium in swine. J. Interv. Card. Electrophysiol. 14(2):79-87. <http://dx.doi.org/10.1007/s10840005-4592-4> <PMid:16374554>

Yamaguchi M., Shimizu M. \& Ino H. 2003. T wave peak-to-end interval and QT dispersion in acquired long QT syndrome: a new index for arrhythmogenicity. Clin. Sci., London, 105(6):671-676. <http://dx.doi. org/10.1042/CS20030010> <PMid:12857349>

Zhao X., Xie Z. \& Chu Y. 2012. Association between Tp-e/QT ratio and prognosis in patients undergoing primary percutaneous coronary intervention for ST-segment elevation myocardial infarction. Clin Cardiol. 35(9):559-564. <http://dx.doi.org/10.1002/clc.22022> <PMid:22740086>

Zorzi A., Migliore F. \& Elmaghawry M. 2013. Electrocardiographic predictors of electroanatomic scar size in arrhythmogenic right ventricular cardiomyopathy: implications for arrhythmic risk stratification. J. Cardiovasc. Electrophysiol. 24(12):1321-1327. <http://dx.doi.org/10.1111/jce.12246>

Zumhagen S., Zeidler E.M. \& Stallmeyer B. 2016. $\mathrm{T}_{\text {peak }}{ }^{-\mathrm{T}_{\text {end }}}$ interval and $\mathrm{T}_{\text {peak }}{ }^{-}$ $\mathrm{T}_{\text {end }} / \mathrm{QT}$ ratio in patients with Brugada syndrome. Europace 18(12):18661872. <http://dx.doi.org/10.1093/europace/euw033><PMid:26941339> 